\title{
PENGARUH POLA ASUH ORANG TUA DAN SIKAP BAHASA \\ TERHADAP KEMAMPUAN MEMBACA PEMAHAMAN
}

\author{
ARIF ISMAIL SANTOSA \\ Universitas Negeri Jakarta Indonesia \\ arifismail1969@gmail.com \\ Pertama Diterima: I 5 Maret 2018 \\ Bukti Akhir Diterima: 10 Desember 2018
}

\begin{abstract}
Abstrak
Penelitian ini bertujuan untuk mengetahui (1) pengaruh pola asuh orang tua dan sikap bahasa secara bersama sama terhadap kemampuan membaca pemahaman; dan (2) pengaruh pola asuh orang tua dan sikap bahasa, masing-masing terhadap kemampuan membaca pemahaman. Penelitian ini menggunakan pendekatan kuntitatif dengan metode deskriptif. Pengumpulan data menggunakan kuesioner dan tes objektif. Kuesioner digunakan untuk mengumpulkan data pola asuh orang tuan dan sikap bahasa. Tes objektif digunakan untuk mengumpulkan data kemampuan membaca pemahaman. Sampel penelitian ini berjumlah 69 orang, Analisis data menggunakan statistik deskriptif dengan menggunakan teknik analisis regresi. Hasil penelitian menunjukkan (1) terdapat pengaruh positif dan signifikan pola asuh orang tua, sikap bahasa, secara bersama sama terhadap kemampuan membaca pemahaman siswa kelas VII SMP Negeri 177 Jakarta sebesar 85,5\%; dan (2) terdapat pengaruh positif dan signifikan pola asuh terhadap kemampuan membaca sebesal 38,7\%; sikap bahasa terhadap kemampuan membaca sebesar 10,2\%
\end{abstract}

Kata kunci : kemampuan membaca pemahaman, pola asuh orang tua, sikap bahasa

\section{Abstract}

This study is aimed to determine: (1) the influence of parenting style and language attitudes toward the reading comprehension achievement simultenously; (2) the influence of parenting style and language attitude toward the reading comprehesion achievement respectively. This research applied a quantitative approach underlying on descriptive method. The data collection used questionnaires and objective tests. Questionnaires were used to collect the data on parenting style and language attitudes, and the objective testswere used to collect the data of reading comprehension achievement. The samples of this study amounted to 69 people, and the analysis of this study used descriptive statistic namely regression analysis technique. The result of the research showed: (1) there was positive and significant influence of parenting style and language attitude toward reading comprehension achievement of the grade VII students of The State Junior High School 177 Jakarta 
about $85.5 \%$; (2) there was a positive and significant influence of parenting style toward the reading comprehension achievement about $38.7 \%$, and language attitudes towards reading comprehension achievement was about $10.2 \%$.

Keywords: language attitude, parenting, reading comprehension achievement

\section{PENDAHULUAN}

Lingkungan pedidikan yang paling berpengaruh terhadap pendidikan adalah lingkungan keluarga serta pendidikan di sekolah (Tirtaharja: 2008). Situasi keluarga sangat berpengaruh terhadap perkembangan bahasa anak sebab anak belajar dari situasi dimana anak tumbuh dan dibesarkan di lingkungan tersebut (Djaal: 2008). Dalam tahap pertumbuhan, bahasa anak akan mengalami perkembangan yang dimulai dari menyimak berbicara, membaca, dan menulis pada tahap berikutnya.

Situasi keluarga yang demokratis penuh dengan penghargaan akan berpengaruh terhadap penguasaan aspek perkembangan bahasa anak. Jika seorang anak berbahasa, kemudian mendapatkan respon positif dari keluarga, maka hal itu akan direspon kembali oleh anak dengan positif pula. Hasilnya kemampuan berbahasa anak akan semakin baik. Anak yang merasa mendapatkan stimulus yang baik terhadap keterampilan membaca pemahaman dari keluarga, akan meningkatkan prestasi mereka di sekolah. Hal itu berarti pola asuh orang tua akan berpengaruh positif terhadap prestasi anak di sekolah termasuk prestasi atau keterampilan membaca pemahamannya di sekolah.

Menurut Harington dan Whiting dikutip oleh Gibson menyatakan "pola asuh adalah seluruh interaksi antarorang tua dan anak. Dalam interaksi tersebut terdapat cara berkomunikasi, menghargai, memperhatikan, mendisiplinkan dan bersikap terhadap anak (Utama: 2000). Menurut Santosa, pola asuh adalah cara pendekatan orang dewasa kepada anak dalam memberikan bimbingan, arahan, pengaruh dan pendidikan supaya anak menjadi dewasa dan mampu berdiri sendiri.

Pola asuh orang tua dalam penelitian ini adalah persepsi seorang anak terahadap interaksi atau cara pendekatan antara orang tua kepada anak dalam memenuhi kebutuhan fisik maupun psikis agar anak dapat hidup selaras dengan lingkungan. Cara pendekatan kecenderungannya dapat bersifat otoriter, permisif atau demokratis

Sikap merupakan aspek penting yang dimiliki seseorang untuk menentukan tindakan terhadap suatu objek. Jika sikap terhadap bahasa Indonesia positif berarti juga berpengaruh terhadap keterampilan membaca pemahaman.

Kridalaksana menyatakan sikap bahasa adalah posisi mental atau perasaan terhadap bahasa sendiri atau bahasa orang lain (Kridalaksanan: 2001). Sikap bahasa dapat diamati melalui perilaku berbahasa atau berilaku tutur.

Garvin dan Mathiot merumuskan tiga ciri sikap bahasa yaitu (1) Kesetiaan Bahasa (Language Loyaly) adalah sikap yang mendorong masyarakat turut mempertahankan kemandirian bahasanya termasuk memperkecil masuknya pengaruh luar atau asing. (2) Kebanggaan Bahasa (Language pride) merupakan sikap yang mendorong seseorang menjadikan bahasanya sebagai lambang identitas pribadi atau kelompoknya dan sekaligus membedakannya dari orang atau kelompok lain. (3) Kesadaran adanya norma bahasa (Awarness Of the Norm) adalah sikap yang mendorong penggunaan 
bahasa secara cermat, benar, santun dan layak. Kesadaran demikian merupakan faktor yang sangat menentukan perilaku tutur dalam wujud pemakaian bahasa (language used).

Sikap bahasa dalam penelitian ini adalah pola pikir dan perilaku penutur terhadap bahasa Indonesia yang digunakan siswa yang berkaitan dengan komponen kognitif, afektif, dan konatif. Kognitif berkaitan dengan pengetahuan dan norma bahasa yang benar atau salah, baik atau buruk, diinginkan atau tidak diinginkan, afektif berkaitan dengan kesetiaan dan penilaian suka atau tidak suka (Suhardi:1996), dan konatif berkaitan dengan keganggaan berbahasa, kecenderungan untuk bertindak.

Rubin dalam Samsu Somadayo mengungkapkan bahwa membaca pemahaman adalah proses intelektual yang kompleks yang mencakup dua kemampuan utama, yaitu penguasaan makna kata dan kemampuan berpikir tentang konsep verbal (Somadayo: 2011). Pemahaman terhadap suatu bahan bacaan tidak hanya bergantung pada apa yang terdapat dalam bacaan saja, melainkan juga bergantung pada pengetahuan sebelumnya yang telah dimiliki pembaca. Proses seperti inilah pembaca secara aktif membangun pemahamannya terhadap bacaan.

Menurut Burns dan Roes (dalam Hairuddin at al: 2007) membaca pemahaman terdiri empat tingkatan, yaitu pemahaman literal (literal comprehension), pemahaman interpretatif (interpretative comprehension), pemahaman kritis (critical comprehension) dan pemahaman kreatif (creative comprehension).

Pemahaman literal adalah pemahaman terhadap apa yang dikatakan atau disebutkan penulis dalam teks bacaan (Somadayo:2011). Pemahaman ini diperoleh dengan memamhami arti kata, kalimat dan paragraf dalam konteks bacaan itu seperti apa adanya. Dalam pemahaman literal ini tidak terjadi pendalaman pemahaman terhadap isi informasi bacaan. Yang terjadi hanya mengenal dengan mengingat apa yang tertulis dalam bacaan.

Membaca interpretatif merupakan kegiatan membaca yang berusaha memahami apa yang dimaksudkan oleh penulis dalam teks bacaan. Menurut Syafi'ie (1999) pemahaman interpretatif harus didahului pemahaman literal yang aktivitasnya berupa: menarik kesimpulan, membuat generalisasi, memahami hubungan sebab-akibat, membuat perbandingan-perbandingan, menemukan hubungan baru antara fakta-fakta yang disebutkan dalam bacaan (Syafi'ie: 1999).

Membaca kritis merupakan membaca yang bertujuan untuk memberikan penilaian terhadap sesuatu teks bacaan dengan jalan melibatkan diri sebaik-baiknya ke dalam teks bacaan itu. Selanjutnya menurut Burns dalam Samsu (Somadoyo: 2011) membaca kritis adalah mengevaluasi materi tertulis, yakni membandingkan gagasan yang tercakup dalam materi dengan standar yang diketahui dan menarik kesimpulan tentang keakuratan, dan kesesuaian. Pembaca kritis harus bisa menjadi pembaca yang aktif, bertanya, meneliti fakta-fakta, dan menggantungkan penilaian/keputusan sampai ia mempertimbangkan semua materi.

Membaca kreatif merupakan tingkatan membaca pemahaman pada level yang paling tinggi. Proses membaca kreatif ini menurut Syaf'ie dimulai dari memahami bacaan secara literal kemudian menginterpretasikan dan memberikan reaksinya berupa penilaian terhadap apa yang dikatakan penulis, dilanjutkan dengan mengembangkan pemikiran-pemikiran sendiri untuk membentuk gagasan, wawasan, pendekatan dan pola-pola pikiran baru (Syafi'ie: 1999).

Kemampuan membaca pemahaman dalam penelitian ini adalah suatu kemampuan literal yang 
melibatkan kegiatan menangkap arti lambang-lambang tertulis dan dapat menginterpretasikan pesan tertulis baik secara tersirat maupun tersurat. Kemampuan membaca literal yang terdiri atas: mengetahui judul bacaan, mengetahui makna kata, tokoh utama, sebab akibat, serta menarik kesimpulan. Kemampuan interpretasi yang terdiri atas: menginterpretasikan pesan cerita, meninterpretasikan perbandingan, menginterpretasikan ciri-ciri cerita dan mengambil kesimpulan.

Dengan demikian, dalam penelitian ini akan membuktikan bahwa pertama apakah benar pola asuh orang tua berpenagaruh kepada kemapuan membaca pemahaman siswa dan seberapa besar pengaruhnya; kedua apakah benar sikap bahasa berpengaruh terhadap kemampuan membaca pemahaman seorang siswa dan seberapa besar pengaruhnya; ketiga bagaimana pala asuh dan sikap bahasa secara bersama-sama berpengaruh terhadap kemampuan membaca pemahaman siswa SMP.

\section{METODE PENELITIAN}

\section{Pendekatan Penelitian}

Pendekatan menggunakan pendekatan kuantitatif asosiatif.

\section{Populasi dan Sampel}

Penelitain ini dilakukan di kelas VII SMP Negeri 177 Jakarta Selatan pada tahun pelajaran 2016/2017 dengan populasi sebanyak 324 siawa yang terdiri dari 6 kelas. Jumlah kelas dari kelas VII - IX seluruhnya ada 27 kelas. Setiap kelas rata-rata 36 siswa. Sampel yang gunakan hanya kelas VII, sedangkan besarnya sampel yang ditetapkan menggungakan rondom sampling $21 \%$ yaitu sebanyak 69 orang.

\section{Teknik Pengumpulan Data}

Pengumpulan data menggunakan kuesioner dan tes objektif yang terlebih dahulu dilakukan uji validitas dan reliabilitas dengan menggunakan rumus korelasi Pearson Produc Moment dan Judgement validity, perhitungan reliabilitas menggunakan teknik alpha cronbach dan KR 20.

\section{Teknik Analisis Data}

Data yang diperoleh dari hasil penellitian dianalisis dengan analisis deskriptif dan inferensial. Analisis deskriptif digunakan untuk memperoleh gambaran karakteristik variabel penelitian. Sedangkan analisis inferensial digunakan untuk menguji hipotesis. Sebelum dilakukan analisis terlebih dahulu dilakukan uji normalitas, linieritas dan homogenitas. Untuk menguji hipotesis digunakan teknik analisis data dengan model regresi ganda. Analisis regresi ganda dipergunakan untuk mengetahui kontribusi masing-masing variabel independent terhadap variabel dependen. Analisis regresi ganda dilakukan dengan program SPSS versi 21.

\section{Instrumen}

Instrumen kempuan membaca difokuskan pada pemahaman literal dan pemahaman interpretasi. Penjelasan lebih lanjut terdapat pada Tabel 1 berikut. 
Tabel 1 Kisi-kisi Instrumen Kemampuan Membaca Pemahaman (X3)

\begin{tabular}{|c|c|c|c|c|c|}
\hline NO & VARIABEL & DIMENSI & INDIKATOR & NO. BUTIR & JUMLAH \\
\hline \multirow[t]{10}{*}{1.} & \multirow{10}{*}{$\begin{array}{l}\text { Kemampuan } \\
\text { m e m b a c a } \\
\text { pemahaman }\end{array}$} & \multirow{5}{*}{$\begin{array}{l}\text { Pemahaman } \\
\text { Literal }\end{array}$} & 1.Mengetahui judul & 1,16 & 2 \\
\hline & & & 2.Mengetahui makna kata & 14,23 & 2 \\
\hline & & & 3.Mengenali tokoh utama & $3,4,8,18,22$ & 5 \\
\hline & & & 4.Mengenali sebab-akibat & $7,9,10$ & 3 \\
\hline & & & 5.Urutan tempat kejadian & $\begin{array}{l}2,11,19,12, \\
13\end{array}$ & 5 \\
\hline & & \multirow[t]{4}{*}{$\begin{array}{l}\text { Pemahaman } \\
\text { Interpretasi }\end{array}$} & $\begin{array}{l}\text { a.Menginterpretasikan } \\
\text { pesan cerita }\end{array}$ & 5,20 & 2 \\
\hline & & & $\begin{array}{l}\text { b.Menginterpretasikan } \\
\text { perbandingan }\end{array}$ & $6,17,21$ & 3 \\
\hline & & & $\begin{array}{l}\text { c. Menginterpretasikan ciri- } \\
\text { ciri ide cerita }\end{array}$ & 15,24 & 2 \\
\hline & & & d.Mengambil kesimpulan & 25 & 1 \\
\hline & & & Jumlah & & 25 \\
\hline
\end{tabular}

Instrumen pola asuh orang tua dikembangkan berdasarkan kencenderungan pola asuh oang tua yang bersifat otoriter, permisif dan demokratis terlihat pada Tabel 2 berikut ini.

Tabel 2 Kisi-Kisi Instrumen Pola Asuh Orang Tua (X1)

\begin{tabular}{|c|c|c|c|c|}
\hline NO & $\begin{array}{c}\text { SUB } \\
\text { VARIABEL }\end{array}$ & INDIKATOR & NO PERNYATAAN & $\begin{array}{l}\text { JUMLAH } \\
\text { SOAL }\end{array}$ \\
\hline \multirow[t]{6}{*}{1.} & \multirow[t]{6}{*}{ Otoriter } & 1.Tegas & 3,17 & 2 \\
\hline & & 2.Suka menghukum & $11,12,15$ & 3 \\
\hline & & 3.Tidak simpatik & $5,13,14,16,2,4$ & 4 \\
\hline & & $\begin{array}{l}\text { 4.Memaksa anak patuh } \\
\text { terhadap nilai orang tua }\end{array}$ & 7,8 & 2 \\
\hline & & $\begin{array}{l}\text { 5.Membentuk perilaku anak } \\
\text { sesuai perilakunya sendiri }\end{array}$ & 6,9 & 2 \\
\hline & & $\begin{array}{l}\text { 6.Cenderung mengekang } \\
\text { keinginan anak }\end{array}$ & 1,10 & $\begin{array}{l}2 \\
2\end{array}$ \\
\hline \multirow[t]{4}{*}{2.} & \multirow[t]{4}{*}{ Permisif } & $\begin{array}{l}\text { 1.Memberikan kebebasan } \\
\text { kepada anak }\end{array}$ & $19,20,21$ & 3 \\
\hline & & $\begin{array}{l}\text { 2.Tidak menuntut tanggung } \\
\text { jawab anak }\end{array}$ & 18,22 & 2 \\
\hline & & 3.Tidak banyak mengontrol & 23,24 & 2 \\
\hline & & 4.Tidak mempedulikan anak & 25. & 1 \\
\hline
\end{tabular}


3. Demokratis

$\begin{array}{lll}\begin{array}{ll}\text { 1.Mengontrol dan } \\ \text { mendorong anak untuk }\end{array} & 3 \\ \text { maju } & 36,39,40, & 4 \\ \begin{array}{l}\text { 2.MemberI contoh dan } \\ \text { membimbing }\end{array} & 27,28,32,38, & 2 \\ \begin{array}{l}\text { 3.Melatih untuk } \\ \text { bertanggung jawab }\end{array} & 29,26 & 6 \\ \begin{array}{l}\text { 4.Menghargai dan } \\ \text { bekerjasama }\end{array} & 30,31,33,34,35,37 \\ \quad \text { Jumlah } & & 40\end{array}$

Instrumen sikap bahasa dikembangkan dengan memperhatikan dimensi konatif, afektif, dan kognitif. Penjelasan lebih lanjut pada tabel berikut.

Tabel 3 Kisi-kisi Instrumen Sikap Bahasa (X2)

\begin{tabular}{|c|c|c|c|c|}
\hline No. & Dimensi & Indikator & No. Butir Soal & Jumlah \\
\hline \multirow{2}{*}{1} & \multirow{2}{*}{ Konatif } & Mempertahankan & $1,2,3,4,5,6,7,8,23,30,31,38$ & 11 \\
\hline & & Mencegah pengaruh & $11,22,24,25,32,35$ & 6 \\
\hline \multirow{2}{*}{2} & \multirow{2}{*}{ Afektif } & Kesetiaan & $10,13,21,26,27,28,29,39$ & 8 \\
\hline & & Kebanggaan & $9,12,14,17,19$ & 5 \\
\hline \multirow{3}{*}{3} & \multirow{2}{*}{ Kognitif } & Cermat berbahasa & $6,15,18,33,34,37$ & 6 \\
\hline & & Tertib berbahasa & $16,20,36,40$ & 4 \\
\hline & \multicolumn{3}{|c|}{ Jumlah } & 40 \\
\hline
\end{tabular}

\section{HASIL PENELITIAN DAN PEMBAHASAN}

Penelitian lain yang pernah dilaksanakan berkaitan dengan pola asuh orang tua dan kemampuan berbahasa antara lain dilakukan oleh Joni dalam jurnal artikelnya berjudul "Hubungan Pola Asuh Orang Tua Terhadap Perkembangan Bahasa Anak Prasekolah (3-5 Tahun) di PAUD Al-Hasanah Tahun 2014" (Joni ; 2014). Hasilnya terdapat hubungan antara pola asuh orang tua terhadap perkembangan bahasa anak. Dari sampel penelitian berjumlah 30 anak diperoleh hasil uji chi-square didapatkan nilai $p$ value 0,015 lebih kecil dari pada nilai $\alpha$ yaitu 0,05 . Sementara itu, penelitian lain dilakukan oleh Muryanti dalam jurnal artikelnya berjudul "Peran Pola Asuh Orang Tua dalam Kemampuan Bahasa Anak Usia 4 - 5 Tahun di TK Bayangkari Surakarta" tahun 2013 (Muryanti: 2013) menunjukkan bahwa tidak ada hubungan pola asuh orangtua dengan perkembangan bahasa anak usia 4-5 tahun, dengan ditandai nilai $p$ value sebesar $0.400>0,05$.

Kedua penelitian tersebut memfokuskan pada pola asuh orang tua, perkembangan bahasa, dan kemampuan bahasa. Sedangkan sampel penelitian merujuk pada anak pra sekolah umur 3-5 tahun. Oleh karena itu penelitian yang saya lakukan ini dapat melengkapi penelitian yang sadah ada tersebut dengan memfokuskan pada kemampuan berbahasa terutama kemampuan membaca pemahaman dan sampel penelitian siswa kelas VII SMP. Hasilnya dapat diuraikan pada pemebahasan berikut. 


\section{Kemampuan Membaca Pemahaman (Varibel Dependen)}

Instrumen kemampuan membaca pemahaman terdiri atas 25 item pertanyaan. Secara teoretik rentang skor yang diperoleh dari sampel adalah $0-25$. Setiap nomor berbobot 4 , sehingga skor terendah 0 - 100 Hasil pengumpulan data menunjukan rentang skor 32 - 100, artinya secara empirik diperoleh skor terendah 32 dan skor tertinggi 100, dengan nilai skor rentang sebesar 68 . Nilai rata-rata penguasaan kosa kata sebesaar 66,72 dengan standar deviasi 16,646.

Distribusi kemampuan membaca pemahaman secara rinci disajikan dalam tabel berikut ini.

Tabel 4 Distribusi Skor Kemampuan Membaca Pemahaman

\begin{tabular}{cccc}
\hline No & Kelas Interval & Frekuensi Absurd & Frekkuensi komulatif \\
\hline 1 & $32-42$ & 6 & 6 \\
2 & $43-51$ & 6 & 12 \\
3 & $52-61$ & 12 & 24 \\
4 & $62-71$ & 18 & 42 \\
5 & $72-81$ & 15 & 57 \\
6 & $82-90$ & 6 & 63 \\
7 & $91-100$ & 6 & 69 \\
\hline
\end{tabular}

Berdasarkan Tabel 4 tersebut dapat dilihat bahwa skor kemampuan membaca pemahaman yang memiliki frekuensi yang paling banyak adalah 18 yang berada pada kelas interval $62-71$. Ini berarti kemampuan membaca pemahaman masih cukup karena di angka rata-rata

\section{Pola Asuh Orang Tua ( Variabel Independen}

Instrumen pola asuh terdiri dari 39 item pertanyaan. Secara teoretik rentang skor yang diperoleh dari sampel adalah 39 - 195. Berdasarkan tabel 5 di bawah ini terlihat bahwa variabel pola asuh memiliki rentang skor 80 - 153, artinya secara empiric skor terendah 80 dan tertinggi 153 dengan rentang nilai sebesar 73. Adapun nilai rata-rata pola asuh sebesar 122,86 dengan standar deviasi 17,053 .

Distribusi skor pola asuh orang tua disajikan dalam bentuk tabel distribusi frekuensi sebagai berikut.

Tabel 5 Distribusi Skor Pola Asuh Orang Tua

\begin{tabular}{cccc}
\hline No & Kelas Interval & Frekuensi Absurd & Frekkuensi komulatif \\
\hline 1 & $80-89$ & 3 & 3 \\
2 & $90-100$ & 1 & 4 \\
3 & $101-110$ & 17 & 21 \\
4 & $111-121$ & 7 & 28 \\
5 & $122-131$ & 18 & 46 \\
6 & $132-142$ & 13 & 59 \\
7 & $143-153$ & 10 & 69 \\
\end{tabular}


Berdasarkan Tabel 5 tersebut terlihat bahwa skor pola asuh orang tua memiliki frekuensi yang paling banyak adalah 18 yang berada pada kelas interval $122-131$. Artinya pola asuh orang tua masih cukup demokratis.

\section{Sikap Bahasa (Variabel Independen)}

Instrumen sikap bahasa (X2) terdiri atas 38 item pertanyaan, secara teoretik rentang skor yang diperoleh dari sampel adalah 38 - 190. Berdasarkan tabel 6, di bawah variabel sikap bahasa memiliki rentang skor 79 - 161, ini berarti secara empiric skor terendah 79 dan skor tertinggi 161 dengan nilai rentang skor sebesar 82. Adapun nilai rata-rata sikap bahasa sebesar 127, dengan standar deviasi 18,838. Distribusi skor sikap bahasa secara rinci disajikan dalam bentuk tabel frekuensi sebagai berikut.

Tabel 6 Distribusi Skor Sikap Bahasa

\begin{tabular}{cccc}
\hline No & Kelas Interval & Frekuensi Absurd & Frekuensi komulatif \\
\hline 1 & $79-90$ & 3 & 3 \\
2 & $91-101$ & 2 & 5 \\
3 & $102-113$ & 13 & 18 \\
4 & $114-125$ & 14 & 32 \\
5 & $126-137$ & 13 & 45 \\
6 & $138-148$ & 12 & 57 \\
7 & $149-161$ & 12 & 69 \\
& Jumlah & 69 &
\end{tabular}

Berdasarkan Tabel 6 tersebut dapat dilihat bahwa skor sikap bahasa yang memiliki frekuensi paling banyak adalah 14 yang berada pada kelas interval 114 - 125. Ini berarti sikap bahasa siswa cukup positif.

\section{Uji Validitas dan Reliabilitas Instrumen}

Uji validitas dalam penelitian ini dilakukan dua kali dari setiap instrumen yang akan digunakan untuk mengumpulkan data. Uji validitas dilakukan dengan membandingkan hasil r Pearson Produc Moment dengan $\mathrm{r}$ tabel. Selanjutnya dilakukan uji t dengan membandingkan $\mathrm{t}$ hitung dengan $\mathrm{t}$ tabel. Jika $r$ hitung maupun $\mathrm{t}$ hitung $<\mathrm{r}$ tabel atau $\mathrm{t}$ tabel maka nomor item tersebut diperbaiki dan diuji cobakan kembali. Akhirnya diperoleh item soal yang valid. Hasil uji coba validitas terlihat pada tebel berikut ini.

Tabel 7. Uji Coba Validitas.

\begin{tabular}{lccccc}
\hline \multicolumn{1}{c}{ Variabel } & \multicolumn{2}{c}{ Uji Coba 1 } & \multicolumn{2}{c}{ Uji Coba 2 } & Kesimpulan \\
\hline & Jumlah & Jumlah & Jumlah & Jumlah & Item soal \\
& Soal & Valid & Soal & Valid & digunakan \\
Pola Asuh & 40 & 16 & 40 & 39 & 39 \\
Sikap Bahasa & 40 & 8 & 40 & 38 & 38 \\
Kemampuan Membaca & 25 & 10 & 25 & 25 & 25 \\
\hline
\end{tabular}

Kesimpulannya, jumlah item soal yang digunakan untuk mengumpulkan data dari setiap 
variabel pola asuh ada 39 item, sikap bahasa 38 item, dan kemampuan membaca 25 item.

Uji reliabilitas dilakukan terhadap soal yang sudah valid dengan rumus alpha cronbach dan KR 20. Pengujian dilakukan dengan membandingkan $\mathrm{r}$ hitung dengan $\mathrm{r}$ tabel, sedangka untuk variabel kemampuan membaca dengan membandingkan hasil KR 20 dengan batas minimal yang harus dipenuhi. Hasilnya sebagai berikut.

Tabel 8 Rekapitulalsi Uji Reliabilitas

\begin{tabular}{lllll} 
Variabel & $\mathbf{r}_{\text {hitung }}$ & $\mathbf{r}_{\text {tabel }}$ & Pengujian & Kesimpulan \\
\hline X1(pola asuh orang tua) & $\mathbf{0 , 8 6 3}$ & $\mathbf{0 , 3 2 0}$ & $\mathrm{r}_{\text {hitung }}>\mathrm{r}_{\text {tabel }}$ & Reliabel \\
X2 (sikap bahasa) & $\mathbf{0 , 8 2 1}$ & $\mathbf{0 , 3 2 5}$ & $\mathrm{r}_{\text {hitung }}>\mathrm{r}_{\text {tabel }}$ & Reliabel \\
\hline Variabel & KR20 & min & Pengujian & Kesimpulan \\
\hline $\begin{array}{l}\text { X3 (kemampuan membaca } \\
\text { pemahaman) }\end{array}$ & $\mathbf{0 , 8 8 9}$ & $\mathbf{0 , 7 0 0}$ & KR20 $>0,700$ & Reliabel \\
\hline
\end{tabular}

Dengan demikian uji valditas dan reliabilitas sudah terpenuhi.

\section{Uji Normalitas, Linieritas, dan Homogenitas}

Sesuai dengan tujuan penelitian untuk mengatahui pengaruh variabel bebas terhadap variabel terikat ada beberapa persyaratan yang harus dipenuhi, yaitu uji normalitas, uji liniertias, dan uji homogenitas.

Uji normalitas dalam penelitian ini menggunakan Kolmogorof-smirnov dengan ketentuan pengujian : jika sig $>\alpha(0,05)$ maka disimpulkan data berdistribusi normal. Sebaliknya, jika sig $<$ $\alpha(0,05)$, maka disimpulkan data tidak berdistribusi normal. Dari pengujian dengan menggunakan SPSS diperoleh hasil sebagai berikut.

Tabel 9 Rekapitulasi Uji Normalitas Data Setiap Variabel

\begin{tabular}{|c|c|c|c|c|c|}
\hline Data Variabel & $\mathrm{n}$ & Kolmogorov-Smirnov (Sig) & Shapiro-Wilk (Sig) & Sig & Kesimpulan \\
\hline $\mathrm{X}_{1}$ & 69 & 0,175 & 0,092 & 0,05 & Normal \\
\hline $\mathrm{X}_{2}$ & 69 & 0,200 & 0,468 & 0,05 & Normal \\
\hline $\mathrm{Y}$ & 69 & 0,087 & 0,468 & 0,05 & Normal \\
\hline
\end{tabular}

Uji homogenitas dalam penelitian ini menggunakan Levene dengan IBM SPSS dengan ketentuan pengujian : jika sig $>\alpha(0,05)$ maka disimpulkan data berasal dari populasi yang homogen. Sebaliknya, jika sig $<\alpha(0,05)$, maka disimpulkan data berasal dari populasi yang tidak homogen. Dari pengujian dengan menggunakan SPSS diperoleh hasil sebagai berikut.

Tabel 10 Hasil Uji Homogenitas Setiap Variabel

\begin{tabular}{cllrll}
\hline Data Variabel & Jml & Levene Statistic & Sig. & $\alpha$ & \multicolumn{1}{c}{ Kesimpulan } \\
\hline $\mathrm{X}_{1}$ & 69 & 0,02 & 0,98 & 0,05 & Homogen \\
$\mathrm{X}_{2}$ & 69 & 0,35 & 0,70 & 0,05 & Homogen \\
$\mathrm{Y}$ & 69 & 0,49 & 0,61 & 0,05 & Homogen \\
\hline
\end{tabular}


Pengambilan keputusan uji linieritas dilakukan dengan menggunakan Test for Linearity pada program SPSS dengan taraf signifikansi 0,05. Apabila nilai Sig. deviation from linearity lebih besar dari tingkat signifikansi $(\alpha)$, maka regresi linear dapat dipergunakan untuk menjelaskan pengaruh antara variabel-variabel yang ada. Dengan penghitungan SPSS, hasil analisis Deviation from Linearity (ANOVA table) dapat dilihat pada $\mathrm{F}$ hitung $<\mathrm{F}$ tabel dan tingkat signifikansinya $>0,05 \%$. Dengan demikian, dapat disimpulkan linier dan signifikan. Hasil menggunakan SPSS diperoleh hasil sebagai berikut.

Tabel 11 Rekapitulasi Hasil Uji Linieritas

\begin{tabular}{lllll}
\hline $\begin{array}{l}\text { H ubu ng a n } \\
\text { antarvariabel }\end{array}$ & JJml & $\mathrm{F}_{\text {hitung }}$ & $\begin{array}{l}\mathrm{F}_{\text {tabel }} \\
(\alpha=0,05)\end{array}$ & Kesimpulan \\
\hline Y atas $\mathrm{X}_{1}$ & 69 & 1,54 & 1.88 & Linier \\
$\mathrm{Y}_{\text {atas } \mathrm{X}_{2}}$ & 69 & 0,59 & 1,86 & Linier \\
\hline
\end{tabular}

Tabe 12 Rekapitulasi Hasil Uji Signifikansi Persamaan Regresi

\begin{tabular}{lllll}
\hline $\begin{array}{c}\text { Hubungan } \\
\text { antarvariabel }\end{array}$ & Jml & $\begin{array}{c}\text { Taraf } \\
\text { Sigifikansi }\end{array}$ & $\alpha$ & Kesimpulan \\
\hline Y atas $\mathrm{X}_{1}$ & 69 & 0,129 & 0,05 & Signifikan \\
Y atas $\mathrm{X}_{2}$ & 69 & 0,935 & 0,05 & Signifikan \\
\hline
\end{tabular}

\section{Teknik Analisis Regresi Ganda}

Penulis menggunakan analisis data dengan teknik regresi ganda dengan bantuan SPSS versi 21. Hasil analisi data dengan teknik regresi ganda secara keseluruhan dapat disajikan pada Tabel 13 Model Summary Hasil Analisis Regresi Ganda X1 dan X2 dengan Y.

Hipotesis 1, ada pengaruh pola asuh (X1) dan sikap bahasa (X2) secara simultan terhadap kemampuan menulis (Y). Hal ini dapat dibuktikan dengan tabel 13 hasil perhitungan SPSS di bawah ini.

Tabel 13 Model Summary Hasil Analisis Regresi Ganda X1 dan X2 dengan Y

\begin{tabular}{lllll}
\hline Model & $\mathrm{R}$ & $\mathrm{R}$ Square & Adjusted R Square & Std. Error of the Estimate \\
\hline 1 & $.925^{\mathrm{a}}$ & .855 & .850 & 6.438 \\
\hline
\end{tabular}

Predictors: (Constant), SIKAP BAHASA, POLA ASUH

Tabel 14 ANOVAa Hasil Analisis Regresi Ganda X1 dan X2 dengan Y

\begin{tabular}{|c|c|c|c|c|c|c|}
\hline \multicolumn{2}{|c|}{ Model } & Sum of Squares & df & Mean Square & $\mathrm{F}$ & Sig. \\
\hline \multirow{3}{*}{1} & Regression & 16105.844 & 2 & 8052.922 & 194.264 & $.000^{b}$ \\
\hline & Residual & 2735.925 & 66 & 41.453 & & \\
\hline & Total & 18841.768 & 68 & & & \\
\hline
\end{tabular}

Dependent Variable: KEMAMPUAN MEMBACA

Predictors: (Constant), SIKAP BAHASA, POLA ASUH 
Dari Tabel 13 Model Summary Hasil Analisis Regresi Ganda X1 dan X2 dengan Y diperoleh koefisien korelasi ganda R Square $=0,855$. Angka tersebut menunjukkan bahwa pengaruh X1 dan X2 terhadap Y adalah 85,5\% sedangkan sisanya yaitu 14,5\% dipengaruhi variabel lain di luar pola asuh dan sikap bahasa. Angka 85,5\% tersebut menunjukkan keeratan hubungan antara X1 dan X2 dengan Y.

Untuk mengetahui signifikan tidaknya korelasi ganda dilakukan dengan uji F. Hasil uji F pada tebel ANOVA (tabel 14 ANOVAa Hasil Analisis Regresi Ganda X1 dan X2 dengan Y) terlihat harga $\mathrm{F}_{\text {hitung }}$ sebesar 194.264 pada tingkat signifikansi 0,000. Dengan demikian dapat disimpulkan bahwa secara bersama-sama/semultan ada hubungan yang positif dan signifikan antara pola asuh dan sikap bahasa terhadap kemampuan membaca pemahaman.

Hipotesis kedua, ada kontribusi masing-masing variabel X1 (pola asuh) dan X2 (sikap bahasa) terhadap Y (kemampuan membaca pemahaman). Hal ini dapat dilihat pada Tabel 15 berikut ini.

Tabel 15 Coefficients(a) Analisis Regresi Ganda

\begin{tabular}{|c|c|c|c|c|c|c|}
\hline \multirow{2}{*}{\multicolumn{2}{|c|}{ Model }} & \multicolumn{2}{|c|}{$\begin{array}{l}\text { Unstandardized } \\
\text { Coefficients }\end{array}$} & \multirow{2}{*}{$\begin{array}{l}\text { SStandardized } \\
\text { Coefficients } \\
\text { Beta }\end{array}$} & \multirow[t]{2}{*}{$\mathrm{t}$} & \multirow{2}{*}{ Sig. } \\
\hline & & B & Std. Error & & & \\
\hline \multirow{3}{*}{1} & (Constant) & -43.750 & 5.683 & & -7.699 & .000 \\
\hline & POLA ASUH & .607 & .118 & .622 & 5.163 & .000 \\
\hline & SIKAP BAHASA & .282 & .106 & .319 & 2.649 & .010 \\
\hline
\end{tabular}

a. Dependent Variable: KEMAMPUAN MEMBACA PEMAHAMAN

Berdasarkan hasil analisis regresi ganda sebaimana terlihat pada tabel 15. Coefficients(a) Analisis Regresi Ganda di atas terlihat bahwa pola asuh berpengaruh langsung terhadap kemampuan membaca sebesar 0,622 (nilai beta pada tabel 15) atau sebesar $\left(0,622^{2}=0,387=38,7 \%\right) 38,7 \%$. Sedangkan sikap bahasa berpengaruh langsung terhadap kemampuan membaca sebesar 0,319 ( nilai beta pada tabel 9) atau sebesar $\left(0,319^{2}=0,102=10,2 \%\right) 10,2 \%$. Persamaan regresinya adalah Y $=-43,750+0,607 \mathrm{X} 1+0,282 \mathrm{X} 2$. Dengan persaman regresi $\mathrm{Y}=-43,750+0,607 \mathrm{X} 1+0,282 \mathrm{X} 2$ berarti setiap kenaikan satu unit skor pola asuh dan satu unit sikap bahasa secara bersama-sama akan menaikkan tingkat kemampuan membaca siswa sebesar 88,9 pada kostanta $-43,750$. Dari data tersebut dapat diketahui bahwa pola asuh (X1) memberi konstruksi lebih besar jika dibandingkan dengan sikap bahasa terhadap kemampuan membaca siswa.

\section{PENUTUP}

Berdasarkan hasil analisis data menggunakan teknik regresi ganda dengan bantuan program SPSS versi 21 dapat disimpulkan sebagai berikut.

Terdapat korelasi positif dan signifikan antara pola asuh orang tua dan sikap bahasa siswa secara bersama-sama terhadap kemampuan membaca siswa, sebesar 85,5\% Ini berarti semakin baik pola asuh orang tua dan semakin baik sikap bahasa siswa makan semakin tinggi kemampuan membaca pemahaman siswa.

Pola asuh orang tua yang baik dan sikap bahasa seorang siswa yang baik masing-masing 
mempunyai kontribusi yang berarti terhadap kemampuan membaca siswa. Pola asuh orang tua mempunyai kontribusi yang lebih besar, sebesar $\left(0,622^{2}=0,387=38,7 \%\right)$ 38,7\% dibandingkan dengan sikap bahasa sebesar $\left(0,319^{2}=0,102=10,2 \%\right)$ 10,2\%. dalam meningkatkan kemampuan membaca pemahaman siswa.

\section{DAFTAR PUSTAKA}

Davidoff. 1998. Psikologi Suatu Pengantar. Jakarta: Erlangga.

Djaal. 2008. Psikologi Pendidikan. Jakarta: Bumi Aksara.

Gibson, James L., John M. Ivancevich \& James H. Donelly, Jr. Organisasi. 1997. Perilaku Stuktur, Proses. Jakarta: Bina Rupa Aksara.

Hairuddin, dkk. 2007. Pembelajaran Bahasa Indonesia Jakarta: Depdiknas Dirjen Dikti.

Kridalaksanan, Harimurti. 2001. Kamus Linguistik. Jakarta: Gramedia Pustaka Utama.

Maryati. 2014. Peran Pola Asuh Orang Tua dalam Kemampuan Bahasa Anak Usia 4 - 5 Tahun. diunduh di http://jurnal.poltekkes-solo.ac.id/index.php/Int/article/view/52

McShane, Steven L. dan Mary Ann Van Ganov. 2008. Organization Behavior. New York: Inc McGrew-Hill Compainies.

Pardede, Ratlan \& Reinald Manurung. 2014. Analisis Jalur Teori dan Aplikasi dalam Riset Bisnis. Jakarta: Rineka Cipta.

Rakhmat, Jalaluddin. 1989. Psikologi Komunikasi. Bandung:PT Remaja Rosdakarya.

Riadi, Edi. 2016. Statistik Penelitian (Analisis Manual dan IBM SPSS). Yogyakarta: Andi.

Riduwan \& Engkos Acmad Kuncoro. 2014. Cara Menggunakan dan Memaknai Path Analysis (Analisis Jalur). Bandung: Alfabeta.

Robbin, Stephen P. 2006. Perilaku Organisasi, Alih Bahasa: Benyamin Molan. Jakarta: PT 
Prenhallindo.

Sarwono, Sarlito Wiryawan. 1995. Psikologi Lingkungan. Jakarta: Gramedia Widiasarana Indonesia.

Slameto. 2010. Belajar dan Faktor-faktor yang Mempengaruhi. Jakarta: Rineka Cipta.

Somadayo, Samsu. 2011. Strategi dan Teknik Pembelajaran Membaca. Yogyakarta: Graha Ilmu.

Syafi'ie, Imam. 1999. Pengajaran Membaca di kelas-Kelas Awal Sekolah Dasar. Malang: UNM.

Thoha, Miftah. 1993. Tingkah laku Organisasi: Konsep Dasar dan Aplikasinya. Jakarta: CV. Rajawali.

Tirtaraharja, Umar. 2008. Penganatar Pendidikan. Jakarta: Rineka Cipta.

Utama, Maria M. Ze. 2000. Hubungan Pola Asuh Orang Tua dengan Perilaku Agresif Sisiwa SLTP Ghandi Poera. Skripsi. Jakarta.

Walgito, B. 1997. Psikologi Umum.Yogyakarta: Andi Offset. 